\title{
An Integration of Family and School on Strengthening the Character of Teenager in Indonesia: It's a Must
}

\author{
Dwi Hastuti \\ Department of Family and \\ Consumer Sciences, \\ Faculty of Human Ecology, \\ Bogor Agricultural University
}

\author{
Sarwititi Sarwoprasodjo \\ Department of Communication \\ and Community Development \\ Sciences, Faculty of Human \\ Ecology, Bogor Agricultural \\ University
}

\author{
Alfiasari* \\ Department of Family and \\ Consumer Sciences, \\ Faculty of Human Ecology, \\ Bogor Agricultural University
}

*Corresponding author: alfia81@gmail.com

\begin{abstract}
Juvenile delinquencies that have increased in the last few years among teenagers in Indonesia need some integrative efforts to overcome. This study analysed influence of parenting styles, methods of socialization, and school environment on character strengths among teenagers. This study also examined what family and school can do to improve their character strengths. This study involved 400 students conducted in 10 senior high schools in rural and urban area in Bogor, West Java Province, Indonesia. The result of this study revealed that some factors in the family (low level of permissive parenting style, high level of authoritative parenting style, higher variations of methods of socialization) and school environment (low of punishment and low violent behavior received in school, higher preference for learning process and condition at school) had significant and positive influence to increase quality of character. Hence, integration of partnership between family and school to strengthen teenagers' character is discussed further in this study.
\end{abstract}

Keywords: character strengths, methods of socialization, parenting style, school environment

\begin{abstract}
Abstrak. Kenakalan remaja yang telah meningkat dalam beberapa tahun terakhqir di kalangan remaja di Indonesia memerlukan upaya integratif. Penelitian ini menganalisis pengaruh gaya pengasuhan, metode sosialisasi, dan lingkungan sekolah pada kekuatan karakter di kalangan remaja. Penelitian ini juga meneliti hal yang dapat dilakukan keluarga dan sekolah untuk meningkatkan kekuatan karakter remaja. Penelitian ini melibatkan 400 siswa yang dilakukan di 10 SMA di daerah pedesaan dan perkotaan di Bogor, Provinsi Jawa Barat, Indonesia. Hasil penelitian ini menunjukkan bahwa beberapa faktor dalam keluarga (gaya pengasuhan permisif tingkat rendah, gaya pengasuhan otoritatif tingkat tinggi, metode sosialisasi dengan variasi yang tinggi) dan lingkungan sekolah (tingkat hukuman yang rendah dan perilaku kekerasan yang rendah diterima di sekolah, preferensi yang lebih tinggi untuk proses belajar dan kondisi di sekolah) memiliki pengaruh yang positif signifikan untuk meningkatkan kualitas karakter. Oleh karena itu, integrasi kemitraan antara keluarga dan sekolah untuk memperkuat karakter remaja dibahas lebih lanjut dalam penelitian ini.
\end{abstract}

Kata kunci: gaya pengasuhan, kekuatan karakter, lingkungan sekolah, metode sosialisasi 


\section{Introduction}

Juvenile delinquencies among teenagers have increased in the last few years in Indonesia and it shows critical problems in teenagers' behavior. Some cases like suicide, drugs use, free sex, fighting, and bullying happen more frequently among teenagers, especially among high school students. These problems need a comprehensive solution in order to prevent antisocial behavior among teenagers. Some studies mention that antisocial behavior can be affected by individual, family, schools, and also neighbourhood factors (Berns, 1997; Park et al., 2010; McGee et al., 2011). The interaction among these factors can drive antisocial behavior (Borba, 2001). Furthermore, gender, depression, attitude, and peer have strong relation with antisocial behavior in teenagers (Nebbit and Lombe, 2008).

Additionally, since antisocial behavior and character strengths among teenagers are affected by individual, family, and schools factors (Borba, 2001; Park et al., 2010; McGee et al., 2011), an advanced examination to explain relationships between parenting practices, school environment, and also individual factors among teenagers in Indonesia needs to be conducted. Regarding to Bronfenbrenner's concept (Berns, 1997) about ecological environment of child development, parents and schools are people and institutions that interact directly with children in their daily life and activities. This is known as microsystem. A comprehensive analysis on integrative roles of parent and school toward character development to prevent antisocial behavior risk should be reported.

Parents as the closest environment of children and the important roles through parenting were proved in many studies. The positive effect of parenting style on child development has been discussed in some studies such as positive effect of authoritative parenting (Baumrind, 2008), negative correlation between high levels of overprotection and low levels of acceptance with adolescents' self-esteem (Herz and Gullone, 1999), positive influence of authoritative parenting on self-esteem (Martinez, Garcĭa, and Yubero, 2007), and also positive association between authoritative parenting and adolescents' mental health (Dwairy et al., 2006). Meanwhile, the important factors of socialization methods, especially in standard maintenance of family also show positive influence on social competence and positive value among middle school teenagers (Hillaker et al., 2008). Another studies have also revealed that parenting practices influence personality development and emotional adjustment of children that can affect an occurrence of juvenile delinquencies (McKinney, Donnelly, and Renk, 2008; Rebellon, Stracuzzi, and Burbank, 2010; Schofield et al., 2012).

In addition, school factors, including learning process and school environment as an environment that interact directly with teenagers, also determine the formation of characters and positive values in children. Schools have a function as socialization agent to provide rich intellectual and social experience to achieve knowledge, skill and competence using their interest and potency (Berns, 1997). Other study has shown that school condition including school building give impact to student's academic achievement (Durán-narucki, 2008). Furthermore, learning situation and class management also influence students' academic achievement (Gherasim, Mairean, and Butnaru, 2012).

Even though many studies have shown significant roles of parents and schools on children, comprehensive analysis on integrative roles between parents and schools in order to prevent antisocial behavior through strengthening teenagers' character is still 
limited. In this globalization and high-technology era, school and family should work hand in hand to anticipate negative influences of value and life style changes approaching teenagers. In America, there is a Comprehensive School Reform (CSR) applied to improve education system which includes not only using approved method and learning environment but also integrating school based management and community-parents participation as well as supporting teacher to enhance their skill and competency through education and training (Borman et al., 2003). Relevant to those challenges, this research was conducted to examine character strengths of an antisocial behavior, parenting roles measured by parenting styles, parents' methods of socialization and school roles measured by school environment among teenagers in Bogor, West Java Province, Indonesia. Furthermore, the influence of parenting styles, methods of socialization, and school environment on character strengths among teenagers was also examined. In the end of the discussion, the findings will be used as a foundation to create family and school partnership that can be conducted in senior high schools in Indonesia to strengthen the characters and to prevent the antisocial behavior among teenagers.

\section{Method}

\section{Participants}

This research was conducted in 10 senior high schools in rural and urban area in Bogor District. Bogor is one of districts in West Java Province that is located next to Jakarta, the capital city of Republic of Indonesia. The school participants consisted of 4 junior high schools in rural areas and 6 junior high schools in urban areas that consisted of general high school and vocational high school. The population of the research was students in senior high schools in Bogor. Sampling technique used in this research was cluster random sampling which randomly selected the students in each school. This research involved 400 students which consisted of 200 girls and 200 boys, 200 of which were students of high schools in rural areas and the others were students of high schools in urban areas.

This study used cross sectional design in which the data was collected by selfreport from the students assisted by structured questionnaires. Firstly, researchers chose randomly several schools which became site of this study regarding to gender composition of the students. Secondly, the sampling frame of students in the schools was collected, and the samples were chosen by cluster random regarding to the same proportion of girls and boys. The total samples were 400 students consisting of 200 boys and 200 girls.

\section{Measures}

Some variables related with characteristics of family and teenagers were performed as demographic variables. These variables consisted of parents' age, parents' education, parents' occupation, family income, family size, teenagers' age and gender.

Parenting styles in this research were measured by 30 items that measured three styles of parents' interaction with children namely authoritative, authoritarian, and permissive regarding to Baumrind's theory (Baumrind, 2008). This used modification questionnaire of Parental Authority Scales that was developed by Buri (1981). Every 
item of this instrument had four choices of the answer from "strongly agree" until "strongly disagree." It was then measured by Likert scale. In this study, parenting styles measurement was approached by measuring the perception of teenagers on parenting styles. In assessing the type of parenting, this study used the highest score among the three styles as the most dominant type of parenting.

Regarding to Berns (1997), methods of socialization in this research were measured by 40 items that were constructed by five dimensions of socialization methods like modeling, reasoning, positive reinforcing, setting standard, and punishment. Like parenting styles, measurement of socialization methods was also measured by 4 scales of Likert from "strongly agree agree" until "strongly disagree". The measurement of socialization methods also used an approach of teenagers' perception measurement on their parent's socialization method.

As character strengths among teenagers as students of senior high school became other independent variables, school environment was measured by typology of school divided into two types (urban and rural) of punishment and of negative behavior ever received in school, also of student's preference on learning process in school.

Character strengths were measured by six dimensions like respect, tolerance, leadership, empathy, honesty, and responsibility. There were 70 items to measure character strengths of teenagers. The sixth dimensions of character strengths were modified based on The Ninth Pillar of Characters by Indonesia Heritage Foundation as one of pioneer institutions in character education in Indonesia which has developed explicit curricula for character education in Indonesia. This research also measured antisocial behavior as negative aspects of the teenagers' development. Antisocial behavior was measured by frequency of certain behavior occuring during the last six months. The scale of frequent behavior ranged from 0 until 3 which represented never, seldom, often and always respectively.

Data collection was done at schools on two visits in each school. The structured questionnaires were divided into two subsets of questionnaire. Data collection was conducted by filling the structured questionnaires by researcher's or assistant researcher's supervision in the form of self-report of every student as sample (participant). This procedure was conducted in order to minimize the bias in the data collection. Before the participant filled the structured questionnaire, researcher/assistant researcher asked for permission and availability to the participant for being a sample in this research.

\section{Data Analysis}

Descriptive test, t-test, correlation test, and regression test were used to answer the research question. Descriptive test and t-test were used to analyze the mean of each dimension of character strengths among teenagers and to find the differences of each dimension of character strengths among teenagers between urban and rural schools. Meanwhile, correlation test was used to examine the correlation between character strengths and antisocial behavior among teenagers. Furthermore, regression test was used to analyze the influence of parenting styles, methods of socialization, and school environment on character strengths among teenagers.

Before data analysis was conducted, the raw data from measurement of parenting styles, methods of socialization, school environment, and character strengths were transformed into scores by index which had minimum score (0) and maximum score (100). Those index scores were used in data analysis. 


\section{Result}

\section{Character Strengths and Antisocial Behavior in Teenagers}

In this study, characters of teenagers were measured using six dimensions of character namely respect, tolerance, leadership, empathy, honesty, and responsibility. The results showed that six dimensions of teenager character had low average scores. Table 1 shows that in urban area as well as rural area, the dimension of leadership has lowest average scores among other dimensions. Besides, it was found that scores of leadership between urban and rural teenagers were significantly different. Rural teenagers had higher scores of leadership than urban ones. It means that even though both teenagers from rural and urban areas have low scores of leadership, teenagers from rural area still have better knowing, feeling, and acting on leadership than teenagers from urban areas. Furthermore, character of honesty had the highest average scores among other dimensions of character strengths. In line with leadership scores, honesty dimension also showed that teenagers from rural areas had better knowing, feeling, and acting on honesty dimension than urban teenagers. Moreover, character of responsibility, tolerance, respect, and empathy also had higher scores in rural teenagers and it was significantly different between rural and urban teenagers, especially on character of responsibility, respect, and empathy. Based on Table 1, it is indicated that teenagers in rural area have better character than urban, even the average index scores of six dimensions of the character strengths is still lower than 50.

Table 1 Average scores (mean \pm sd) of characters dimensions among teenagers based on area and gender

\begin{tabular}{|c|c|c|c|c|}
\hline \multirow{2}{*}{ Character } & \multicolumn{2}{|l|}{ Urban Area } & \multicolumn{2}{|c|}{ Rural Area } \\
\hline & Boy & Girl & Boy & Girl \\
\hline Respect & $26.5 \pm 3.3$ & $27.0 \pm 3.2$ & $28.2 \pm 3.4$ & $28.4 \pm 3.2$ \\
\hline Mean \pm SD & $26.8 \pm 3.2$ & & 28.3 & \\
\hline$p$-value & \multicolumn{4}{|c|}{$0.000 * *$} \\
\hline Tolerance & $31.4 \pm 2.7$ & $32.0 \pm 3.3$ & $32.0 \pm 3.3$ & $31.4 \pm 3.5$ \\
\hline Mean \pm SD & $31.7 \pm 3.0$ & & 31.7 & \\
\hline$p$-value & \multicolumn{4}{|c|}{0.864} \\
\hline Leadership & $25.0 \pm 3.7$ & $25.6 \pm 3.5$ & $26.6 \pm 3.8$ & $25.8 \pm 4.0$ \\
\hline Mean \pm SD & $25.3 \pm 3.6$ & & 26.2 & \\
\hline$p$-value & \multicolumn{4}{|c|}{$0.027 *$} \\
\hline Empathy & $27.2 \pm 3.0$ & $27.1 \pm 2.9$ & $28.3 \pm 3.1$ & $27.7 \pm 2.9$ \\
\hline Mean \pm SD & $27.1 \pm 3.0$ & & 28.0 & \\
\hline$p$-value & \multicolumn{4}{|c|}{$0.004 * *$} \\
\hline Honesty & $44.7 \pm 5.2$ & $45.6 \pm 5.5$ & $46.1 \pm 5.1$ & $47.2 \pm 5.8$ \\
\hline Mean \pm SD & $45.1 \pm 5.4$ & & 46.6 & \\
\hline p-value & \multicolumn{4}{|c|}{$0.006 * *$} \\
\hline Responsibility & $44.0 \pm 4.6$ & $45.0 \pm 5.3$ & $45.3 \pm 4.7$ & $46.3 \pm 5.3$ \\
\hline Mean \pm SD & \multirow{2}{*}{\multicolumn{4}{|c|}{$\begin{array}{l}\text { 45. } 8 \pm 5.0 \\
0.008^{* *}\end{array}$}} \\
\hline$p$-value & & & & \\
\hline
\end{tabular}

With regard to antisocial behavior, this study also revealed that teenagers with higher scores on characters would have lower scores on negative behavior. The better their characters, it is likely the lesser scores of negative behavior they have, such as smoking, alcohol drinking, drugs addictive, free sex, game on line playing, gangfighting, and bullying (Table 2). 
Table 2 Coefficient and significance values of relationship between variable of characters and antisocial behaviors of teenagers under study

\begin{tabular}{lcccccc}
\hline \multirow{2}{*}{ Antisocial Behaviors } & \multicolumn{5}{c}{ Characters dimensions } \\
\cline { 2 - 6 } & 1 & 2 & \multicolumn{1}{c}{3} & 4 & 5 & 6 \\
\hline Smoking & $-0,257^{* *}$ & $-0,241^{* *}$ & $-0,129^{* *}$ & $-0,129 * *$ & $-0,305^{* *}$ & $-0,419^{* *}$ \\
Alcohol & $-0,235^{* *}$ & $-0,279^{* *}$ & $-0,111^{*}$ & $-0,152^{* *}$ & $-0,258^{* *}$ & $-0,297^{* *}$ \\
Drugs & $-0,204^{* *}$ & $-0,333^{* *}$ & $-0,203^{* *}$ & $-0,066$ & $-0,231^{* *}$ & $-0,273^{* *}$ \\
Free sex & $-0,276^{* *}$ & $-0,205^{* *}$ & $-0,179^{* *}$ & $-0,163^{* *}$ & $-0,318^{* *}$ & $-0,318^{* *}$ \\
Game online addiction & $-0,166^{* *}$ & $-0,194^{* *}$ & $-0,094$ & $-0,082$ & $-0,252^{* *}$ & $-0,247^{* *}$ \\
Gang-fighting & $-0,343^{* *}$ & $-0,287^{* *}$ & $-0,212^{* *}$ & $-0,213^{* *}$ & $-0,385^{* *}$ & $-0,442^{* *}$ \\
Bullying & $-0,233^{* *}$ & $-0,029$ & 0,063 & $-0,185^{* *}$ & $-0,289^{* *}$ & $-0,230^{* *}$ \\
\hline
\end{tabular}

Note. (*) 95\% CI; (**) 99\% CI

$1=$ respect; $2=$ tolerance; 3 = leadership; 4 = empathy; $5=$ honesty; $6=$ responsibility

\section{Parenting Practices among Teenagers in Urban and Rural Area}

Parenting Styles. Baumrind (2008) suggest four types of parenting style which describe warmth/affection and demanding namely authoritative, authoritarian, permissive, and uninvolved parenting style. This research only examined three of them. This study revealed that based on average scores of each dimension of parenting style, most of parents still had low ability to practice positive parenting which is shown by the mean of parenting style index that still lower than 50. Mean and standard deviation of parenting style among teenagers in Table 3 shows that mothers in urban area have higher scores of authoritarian dimension than fathers, as well as mothers in rural area. On the other hand, fathers both areas tend to be more authoritarian than mothers. Like authoritative scores, the permissive scores of mothers tend to be higher than that of fathers in both urban and rural area.

Table 3 Mean and standard deviation of parenting style scores between teenagers on rural and urban area

\begin{tabular}{lcccc}
\hline \multirow{2}{*}{ Dimension of Parenting Style } & \multicolumn{2}{c}{ Urban $(\mathrm{x} \pm \mathrm{SD})$} & \multicolumn{2}{c}{ Rural $(\mathrm{x} \pm \mathrm{SD})$} \\
\cline { 2 - 5 } & Mother & Father & Mother & Father \\
\hline Authoritative & $31.5 \pm 3.6$ & $30.5 \pm 3.7$ & $32.1 \pm 3.8$ & $31.3 \pm 3.3$ \\
Authoritarian & $22.1 \pm 2.9$ & $22.1 \pm 3.2$ & $21.5 \pm 2.2$ & $21.6 \pm 3.4$ \\
Permissive & $21.9 \pm 4.4$ & $21.8 \pm 3.9$ & $22.3 \pm 4.1$ & $22.1 \pm 3.7$ \\
\hline
\end{tabular}

Even though scores of authoritative parenting still was very low (lower than 50) and the difference of mean between positive parenting (authoritative) and negative parenting (authoritarian and permissive) only ranged from 8.7 to 10.6 , mothers and fathers in rural area had better scores on authoritative parenting than teenagers' parents in urban area (Table 3). Furthermore, authoritarian parenting among teenagers' parents in rural area had lower scores than urban parents. Meanwhile, permissive parenting was found in higher scores in rural parents.

Methods of Socialization. In this research, positive encouragement or reinforcement, standard setting, explanation, modelling, and punishment were included in the process of socialization. Most of parents used standard setting, explanation and modelling (26\%; $22 \%$; and $12 \%$ each) to socialize good values to their child, while the rest used a combination of three methods plus positive reinforcement and punishment in this study. 


\section{School Environments in Urban and Rural Area}

In this research, school environments were measured by qualifying the interaction of teenagers with teacher and peer-group, school facilities, school rules, and reinforcement system (punishment and sanction) at school. Teacher-student interaction at school was mostly in moderate quality, but student-peer group interaction was higher than that. Most of teenagers in the study felt more convenience to discuss and interact with peer, and they are open as well to their friends, especially when they experience problems inside or outside school. On the average, most teenagers communicated with teacher related to problems in subject courses, decreasing grade in certain subjects, and remedial for some subject courses.

Meanwhile, school atmosphere could impact student by creating a positive learning environment. More than 60 percent of teenagers perceived that they fond of their school. However, there were 30 percent of teenagers in this study perceived that they dislike their school due to many antisocial behavior or offending students at school, low facilities, low quality of learning process, low competent of teacher, and the distance which is too far from their home.

According to the teenagers' responses, it was shown that within the last six months they ever had experienced punishment, such as pinched their ear, stood outside at noon, did push-up, run surrounding school yard, etc. The punishment is usually physical punishment. It was experienced more by boys rather than girls, indicating that boys are more difficult than girls; therefore, they more often disobey the school rules.

Moreover, this research also found that some of the teenagers also still received verbal, nonverbal, or physical violence (undressing of pants, kicking, hitting, punching, touching). From the comparison between boys and girls, it was revealed that boys had more experience in bullying, which means that boys are more delinquent than girls (Demuth and Brown, 2004).

\section{An Integration of Family and School Partnership to Strengthen Teenagers' Character Strengths}

To answer the question about the role of family and school for character strength, an analysis of factors (home and school environment) that affect character strengths of teenagers is needed. The following model was applied to figure out how families and school could affect character strengths among teenagers in order to determine this. It was shown that family environment worked together with school environment to determine character strength. As shown in Table 4, family environment positively affects character strengths of teenagers through variables of mother's authoritative parenting style and diverse method of socialization applied to children. Meanwhile, mother's permissive style gave a negative effect, indicating that family with mother's permissive parenting style will more likely to have teenagers with lower character, which implies an increase in negative behavior on their teenagers. Meanwhile, both father and mother's method of socialization gave a positive effect on characters strengths of teenagers.

Regarding to school environment, results of multiple regression analysis showed that perception toward school environment and their preference to school system gave significant impact to character strengths (Table 4). Conversely, negative behavior and punishment received by teenagers in their school had a negative effect on their character strengths. Therefore, it implies that teenagers' positive perception toward school and 
good experiences at school are very important and have positive impact to teenager's character strengths in this study.

Table 4 Coefficient of regression analysis of variables that affect character strengths of teenagers

\begin{tabular}{lrrr}
\hline \multirow{2}{*}{ Independent Variables } & \multicolumn{2}{c}{ Coefficient $\beta$} & \multirow{2}{*}{ Significance } \\
\cline { 2 - 3 } Constant & 41.876 & & Standardized \\
Area (0= rural, 1= urban) & -0.521 & -0.044 & 0.000 \\
Age (years) & 0.127 & 0.014 & 0.722 \\
Sex (0= boy, 1= girl) & -0.443 & -0.037 & 0.389 \\
Age of father (years) & -0.056 & -0.062 & 0.274 \\
Age of mother (years) & -0.002 & -0.002 & 0.971 \\
Family size (person) & 0.044 & 0.011 & 0.798 \\
Income per capita (IDR) & $30.14 \mathrm{E}-007$ & 0.036 & 0.389 \\
Father's parenting style of authoritarian (score index) & -0.070 & -0.045 & 0.369 \\
Father's parenting style of permissive(score index) & 0.051 & 0.029 & 0.555 \\
Father's parenting style of authoritative (score index) & 0.002 & 0.001 & 0.981 \\
Mother's parenting style of authoritarian (score index) & 0.116 & 0.083 & 0.106 \\
Mother's parenting style of permissive (score index) & -0.239 & -0.125 & $0.010^{*}$ \\
Mother's parenting style of authoritative (score) & 0.222 & 0.137 & $0.012^{*}$ \\
Method of socialization by father (score index) & 0.101 & 0.210 & $0.004^{* *}$ \\
Method of socialization by mother (score index) & 0.063 & 0.133 & $0.041^{*}$ \\
Peer's relationship (score index) & 0.010 & 0.019 & 0.717 \\
School environment (score index) & 0.067 & 0.170 & $0.000^{* *}$ \\
Punishment received (score index) & -0.112 & -0.113 & $0.010^{*}$ \\
Negative behavior received at school (score index) & -0.167 & -0.123 & $0.003^{* *}$ \\
Preference to school system (score index) & 0.173 & 0.157 & $0.001^{* *}$ \\
\hline Adjusted R Square & & 0.405 & \\
Sig. & & 0.000 & \\
\hline Note. (*) 95\% CI; (**) 99\% CI & & &
\end{tabular}

Compared to home or family environment, the impact of school environment was less dominant as it is shown in the value of unstandardized $\beta$ coefficient. However, the value of an adjusted R-square was 0.405 . It implies that the contribution of variables in this model on character strengths of teenagers are 40.5 percent, while the other 59.5 percent is contributed by other variables excluded in this model.

\section{Discussion}

Antisocial behavior becomes critical issue on teenagers as it correlates with problems of teenagers such as alienated and abused, delinquents, adolescents with emotional disorders, the drug abusers, the smokers, the alcohol abusers, the severely depressed, and so on (Cobb, 2001). The antisocial behavior among teenagers could dangerously affect the development of one nation, hence positive development is an essential issue on teenagers.

The antisocial behavior could be decreased by efforts to encourage teenagers in developing their positive behavior. Since understanding the positive development among teenagers needs comprehensive perspective, character strengths has shown a strong contribution on positive teenagers' development (Park, 2004). Character strengths are classified into six dimensions such as strengths of wisdom and knowledge, courage, humanity, justice, temperance, and transcendence (Peterson and Seligman, 
2004). A study on character strengths and positive development among teenagers has found that some kinds of character strengths had significant role to promote positive teenagers development and to prevent behavior disorder among teenagers (Park, 2004). Studies on empathy, as a virtue of strengths of humanity, show a positive correlation between empathy and pro-social behavior (Roberts and Strayer, 1996, Eisenberg, 2000). A meta-analysis study shows that low cognitive empathy has correlation with offending behavior, and the correlation is stronger in younger people (Jolliffe and Farrington, 2004). In addition, respect and responsibility owned by adolescents can reduce their antisocial behavior (Borba, 2001).

This research found that teenagers in rural area had better character than urban. Why teenagers in urban areas had lower score on their character? Nowadays, in the era of openness of information, teenagers in urban area have greater opportunity to access media which also related with new values and life style. Modernization has somehow influenced communication style, relationship and interaction among peoples, and therefore also gives a negative effect on people in urban setting. They mostly are more individualist and centralist, and also have low empathy, courtesy and respect to others, in an atmosphere of competition and materialism values surrounding them.

Modernization also changes value of people. They become an individual with a strong competition, stress, and pressure to survive. Teenagers of urban area have the access to internet, games, gadget and technology that make them to be more individual and violent (Bushman et al., 2013) while teenagers in rural area have lower access to internet, games, gadget, and technology and tend to be more communal (Heck et al., 2000; Edwards et al., 2000). Hence, teenagers in urban area have stronger bonding with family and their extended family. Therefore, they learn more norms and values in respecting other people. The results of this study revealed that scores of characters dimensions of rural teenagers were higher than that of urban ones. This also confirms the finding of Duhan and Savita (2012) that have revealed significantly higher scores of rural adolescents in their boldness, leadership, sensitivity and social warmth than urban adolescents, which indicate stronger values owned by rural teenagers.

Moreover, a significant correlation between character and antisocial behavior of teenagers in this study reflected that basic goodness such as respect, tolerance, leadership, empathy, honesty, and responsibility could be an effective ways in diminishing antisocial behavior among teenagers. In other word, to form pro-social behavior among teenagers, the characters strengths that could be the individual factors of teenagers should be developed. As mentioned by Lickona (1994), Roberts and Strayer (1996); Eisenberg (2000), Borba (2001), and Megawangi (2004), the basic goodness can eliminate antisocial behavior and lead to pro-social behavior. Hence, antisocial behavior that would give negative impact not only on their individual but also on their social life (Vasallo et al., 2002) can be decreased.

This research also examined the parenting practices of the teenagers' parents. Parenting is a broad concept which includes interaction process between parents and child in rearing children in order to support child growth and development (Brooks, 2001). Regarding to this, parenting style and methods of socialization are crucial aspects to measure how parents interact with their children and how parents socialize values to their children (Berns, 1997; Brooks, 2001); therefore, this could be a predictor for character strengths and antisocial behavior.

Meanwhile, Darling and Steinberg (1993) as cited in Leung et al. (2004) mention that parenting style refers to practice of parents to their children through 
communication and establishing emotional and affective atmosphere. According to Stevens (2008), parenting style is defined as process to explain, direct, give rules to the children and also the way of parents in making communication to child, making discipline, monitoring, and supporting their child (Slicker et al., 2005). It means that parenting style is an approach to reflect quality of parenting through balancing of behavior control and warmth/affection. Based on the result of parents' parenting style, it appears that the ability of the teenagers' parents to implement positive parenting that is in balance between behavior control and warmth is still low, both in rural and urban area. Even in the urban family, the ability of teenagers' parents to practice balanced parenting (authoritative parenting) was much lower. Furthermore, socialization methods that were conducted by the parents showed that only 7-8 percent of parents applied punishment as a way to socialize good habits. Therefore, parenting education is needed to improve knowledge and ability of the parents to conduct more positive parenting practices. Moreover, the finding of school environment also showed that about 30 percent of teenagers in this study perceived that they disliked their school due to many antisocial behavior or offending students at school, low facilities, low quality of learning process, low competent of teacher, and the distance which was too far from their home. It indicates that school should crate a better environment for students that can enhance pro-social behavior as well as character.

The regression analysis firmed that family and school environment had significant influence on improving teenagers' character development. The other variables that could influence character strengths of teenagers are role model given by parents, siblings, neighbours, and friends - not as independent variables in this research. As stated by Campbell and Bond (1982), major factors in the moral development and behavior of teenagers in contemporary America are heredity, early childhood experience, model by important adults and older teenagers, peer influence, the general physical and social environment, the communications media, what is taught in schools and other institutions, specific situations and roles that elicit corresponding behavior. In line with this, it is important to realize that schools do and should play a role in the development of character, families, communities, and society. In general, they also have an important influence (Huitt, 1999; Huitt et al., 2009).

The findings of this research also confirm that integration between family and school play important role to establish better school that could be conducted on several types of school with different social economy background, as well as positive support given by community and government (Borman et al., 2003). Other study done by Martin (2005) offered a support for encouraging positive relationships with school partners including: (1) encouraging parents and communities to be partners in learning, (2) increasing and sustaining school partnership participation, (3) supporting open communication in school partnerships, (4) exploring a variety of roles and responsibilities of school partnerships, (5) recognizing and addressing potential disputes.

Therefore, this study implies practical strategies that can be conducted for family and school to strengthen the character in order to support pro-social behavior among teenagers. At family level, parents should be realized that balancing control behavior and warmth as well as conducting various socialization methods are needed for their teenagers. Besides that, at school level, school management and teachers play an important role to create positive environment for learning process. Those strategies need 
social support especially from community and government in bridging and building a partnership between family and school, especially for teenager in Indonesia.

\section{Conclusion and Recommendation}

\section{Conclusion}

This study showed that teenagers in rural area have better character strengths than those in urban areas, in terms of respect, empathy, honesty, leadership and responsibility. In contrast, teenagers in rural area have lower negative behavior than those in urban area, such as smoking, alcohol drinking, drug addiction, game on-line addiction, gang fighting and bullying. Statistical analysis also showed a negative and significant correlation between character strengths and anti-social behavior of teenagers.

This study also revealed that family and school environment have positive and significant roles to affect character strengths of teenagers. The more authoritative the mother, the better character the teenagers have. Conversely, the more permissive the mother, the worst character the teenagers have.

For school environment, it is important for teenagers to perceive positively to their school environment. The better their preference toward school and school system, the less punishment and negative experiences accepted by teenagers at school, the higher their character strengths are. It is needed for teenagers to have positive curricular and non-curricular activities at school that made them busy and active during weekdays. Therefore, school should provide several alternative curricular and non-curricular activities for students to be selected. The curricular activities could be a science club, English club, writing club, boy and girl's scout; while the non-curricular could be an art painting club, theatre, singing or choir club; and sport club, such as volley ball, badminton, basketball, football, martial art, etc.

\section{Recommendation}

Based on these results, it is recommended for parents and teachers to work hand on hand in shaping and strengthening characters of teenagers as a main factor to initiate pro-social behaviors. Although the age of teenagers in this study is already 15-17 years old, it is still important for parents to take huge responsibility to watch over their teenagers' activities at school and after school every day. Therefore, parents training which focuses on promoting the development of strong family and school bonds is needed. The topic is about family management including establishing appropriate forms of discipline; creating positive home learning environments, supporting their children academically, enforcing drug resistance skills and communicating effectively with their children and their children's teachers.

The result of this study showed that teenagers in urban area have higher access to internet and media information technology; therefore, access to media and information used by teenagers nowadays should be done under the supervision of parents regularly. Besides that, parents should also concern about peer relationship or with whom the teenagers spend their times after school. This study showed that teenagers usually committed to do antisocial behavior with their peers after school, on their way back home. The gang fighting should also be a concern to the government and officers especially in Bogor region where the numbers of gang fighting is 
increasing. Hence, improvement of public facilities, including public transportation for students, sport facilities, public park facilities, is necessary. This is relevant to government plan in supporting a program of City Fit for Children in Bogor region. A regulation and law for smoking and the use of drugs need to be implemented strongly. Hence, law enforcement for vendors and users who violate the rules is strongly recommended because this study found that vendors (big or small stores, smoke vendors or sellers) freely sold ciggareete to children (less than 15 years old).

\section{Acknowledgement}

This study was funded by Directorate of Higher Education, through a National Strategic Research Program, Ministry of Research and Higher Education, Republic of Indonesia in 2012-2014. Therefore, we would like to show our gratitude to the Directorate of Higher Education for giving us an opportunity in conducting this study.

\section{References}

Baumrind, D. (2008). Parental authority and its effect on children. Parenting for Moral Growth (The Council for Spiritual and Ethical Education Newsletter), 1(2).

Berns, R. M. (1997). Child, Family, School, Community: Socialization and Support. Belmont, CA: Holt, Rinehart, and Winston, Inc.

Berkowitz, M. W., \& Bier, M. C. (2005). What Works in Character Education: A Research-Driven Guide for Educators. Character Education Partnership. A John Templeton Foundation.

Borba, M. (2001). Building Moral Intelligence: The Seven Essential Virtues that Teach Kids to Do the Right Thing. San Francisco, CA: Jossey-Bass.

Borman, G. D., Hewes, G. M., Overman, L. T., \& Brown, S. (2003). Comprehensive school reform and achievement: A meta-analysis. Review of Educational Research, 73(2), 125-230. doi: 10.3102/00346543073002125.

Brooks, J. B. (2001). The Process of Parenting (3rd ed.). Toronto, ON: Mayfield Publishing Company.

Buri, J. R. (1991). Parental authority questionnaire. Journal of Personality Assessment, 57(1), 110-119. doi: 10.1207/s15327752jpa5701_13.

Bushman, B. J., Newman, K., Calvert, S. L., Downey, G., Dredze, M., Gottfredson, M., Jablonski, N. G., Masten, A., Morrill, C., Neill, D. B., Romer, D., \& Webster, D. (2013). Youth Violence: What We Need to Know. Report of the Subcommittee on Teenagers Violence of the Advisory Committee to the Social, Behavioural and Economic Sciences Directorate, National Science Foundation.

Campbell, V., \& Bond, R. (1982). Evaluation of a character education curriculum. In D. McClelland (ed.), Education for Values. New York: Irvington Publishers.

Cobb, N. J. (2001). Adolescence: Continuity, Change, and Diversity (4th ed.). Mountain View, CA: Mayfield Publishing Company.

Demuth, S., \& Brown, S. (2004). Family structure, family process, and adolescent delinquency: The significance of parental absence versus parental gender. Journal of Research in Crime and Deliquency, 41(1), 58-81. doi: 10.1177/0022427803256236. 
Duhan, K., \& Savita. (2012). Personality assessment of rural and urban adolescent boys from disorganized families. Journal of Sociology and Social Anthropology, 3(1), 4347.

Durán-narucki, V. (2008). School building condition, school attendance, and academic achievement in New York City public schools: A mediation model. Journal of environment Psychology, 28, 278-286. doi:10.1016/j.jenvp.2008.02.008.

Dwairy, M., Achoui, M., Abouserie, R., \& Farah, A. (2006). Parenting styles, individuation, and mental health of arab adolescents: A third cross-regional research study. Journal of Cross-Cultural Psychology, 37(3), 262-272. doi: 10.1177/0022022106286924.

Edwards, R. W., Stanley, L. R., Marquart, B. S., \& Awaim R. C. (2000). Adolescent substance use in rural and small urban communities. Journal of Rural Community Psychology, E14(1).

Eisenberg, N. (2000). Emotion, regulation, and moral development. Annual Review of Psychology, 51, 665-669. doi: 10.1146/annurev.psych.51.1.665.

Gale, J. A., Lenardson, J. D., Lambert, D., \& Hartley, D. (2012). Adolescent alcohol use: Do risk and protective factors explain rural-urban differences? (Working Paper No. 48). Retrieved from http://muskie.usm.maine.edu/Publications/WP48_Adolescent-Alcohol-Use-RuralUrban.pdf.

Gherasim, L. R., Mairean, C., \& Butnaru, S. (2012). Prediction of school performance: The role of motivational orientation and classroom environment. Procedia Social and Behavioural Sciences, 46, 3931-3935. doi: 10.1016/j.sbspro.2012.06.174.

Heck, K. E., Borba J. A., Carlos, R., Churches, K., Donohue, S., \& Fuller, A. H. (2000). California's rural teenagers. 4-H Center for Teenagers Development Department of Human and Community Development University of California, Davis.

Herz, L., \& Gullone, E. (1999). The relationship between self-esteem and parenting style: A cross-cultural comparison of Australian and Vietnamese Australian adolescents. Journal of Cross-Cultural Psychology, 30(6), 742-761. doi: 10.1177/0022022199030006005.

Hillaker, B. D., Brophy-Herb, H. E., Villarruel, F. A., \& Haas, B. E. (2008). The contributions of parenting to social competencies and positive values in middle school teenagers: Positive family communication, maintaining standards, and supportive family relationships. Family Relations, 57(5), 591-601. doi: 10.1111/j.1741-3729.2008.00525.x.

Huitt, W. (1999, April 20). Implementing effective school achievement reform: Four principles. Paper presented at the School Counseling Summit, Valdosta State University, Valdosta, GA. Retrieved from http://www.edpsycinteractive.org/papers/school_reform.pdf.

Huitt, W., Huitt, M., Monetti, D., \& Hummel, J. (2009). A systems-based synthesis of research related to improving students' academic performance. Paper presented at the 3rd International City Break Conference sponsored by the Athens Institute for Education and Research (ATINER), October 16-19, Athens, Greece.

Jolliffe, D., \& Farrington, D. P. (2004). Empathy and offending: A systematic review and meta-analysis. Aggression and Violent Behaviour, 9(5), 441-476. doi: 10.1016/j.avb.2003.03.001.

Leung, C. Y. W., McBride-Chang, C., \& Lai, B. P.Y. (2004). Relations among maternal parenting style, academic competence, and life satisfaction in Chinese early 
adolescents. Journal of Early Adolescence, 24(2), 113-143. doi: 10.1177/0272431603262678.

Lickona, T. (1994). Raising Good Children, From Birth through the Teenage Years. New York, NY: Bantam Books.

Martin, L. (2005). School Partnerships: A Guide for Parents, Schools, and Communities. Manitoba: the Minister of Education, Citizenship and Teenagers. Manitoba Education, Citizenship and Teenagers, School Programs Division.

Martǐnez, I., Garč̌a, J. F., \& Yubero, S. (2007). Parenting styles and adolescents' selfesteem in Brazil. Psychological Reports, 100, 731-745. doi: 10.2466/PRO.100.3.731-745.

McGee, T. R., Wickes, R., Corcoran, J., Bor, W., \& Najman, J. (2011). Antisocial behaviour: An examination of individual, family, and neighbourhood factors. Trends $\&$ Issues in Crime and Criminal Justice, 410, 1-6. Retrieved from http://www.aic.gov.au/media_library/publications/tandi_pdf/tandi410.pdf.

McKinney, C., Donnelly, R. \& Renk, K. (2008). Perceived parenting, positive, and negative perceptions of parents, and late adolescent emotional adjustment. Child and Adolescent Mental Health, 13(2), 66-73. doi: 10.1111/j.1475-3588.2007.00452.x.

Megawangi, R. (2004). Pendidikan Karakter [Character Education]. Jakarta, Indonesia: IHF-Viscom Pratama.

Nebbitt, V. E., Lombe, M. L. \& Williams, J. H. (2008). Assessing the moderating effects of anxiety sensitivity on antisocial behaviour among urban African American teenagers. Journal of Health Care for the Poor and Underserved, 19, 277-293.

Park, N. S., Lee, B. S., Sun, F., Vazsonyi, A. T., \& Bolland, J. M. (2010). Pathways and predictors of antisocial behaviours in African American adolescents from poor neighborhoods. Children and Teenagers Services Review, 32(3), 409-415. doi: doi: $10.1016 /$ j.childyouth.2009.10.012.

Petersen, C., \& Seligman, M. E. P. (2004). Character Strengths and Virtues: A Classification and Handbook. New York: Oxford University Press.

Rebellon, C. J., Stracuzzi, N. F., \& Burbank, M. (2010). Teenagers opinions matter: Retaining human capital in coos county. Carsey Institute, 19, 1-7.

Roberts, W., \& Strayer, J. (1996). Empathy, emotional expressiveness, and prosocial behaviour. Child Development, 67(2), 449-470. doi: 10.1111/j.14678624.1996.tb01745.x.

Slicker, E. K., Picklesimer, B. K., Guzak, A. K., \& Fuller, D. K. (2005). The relationship of parenting style to older adolescent life-skills development in the United States. Young, 13(3), 227-245. doi: 10.1177/1103308805054211.

Stevens, J. (2008). Parenting Styles. Parenting for Moral Growth (The Council for Spiritual and Ethical Education Newsletter), 1(2), 1.

Schofield, T. J., Conger, R. D., Donnellan, M. B., Jochem, R., Widaman, K. F., \& Conger, K. J. (2012). Parent personality and positive parenting as predictors of positive adolescent personality development over time. Merrill-Palmer Quarterly, 58(2), 255-283. doi: 10.1353/mpq.2012.0008.

Vassallo, S., Smart, D., Sanson, A., Dussuyer, I., Bourne, M., Toumbourou, J., Prior, M., \& Oberklaid, F. (2002). Patterns and precursors of adolescent antisocial behaviour: First Report 2002. Australia: Australian Institute of Family Studies. 